\title{
Kuwait Stock Market Participants' Perceptions of Information Useful to the Investment Decisions
}

\author{
Faisal Alanezi $^{1}$, Mishari Alfraih ${ }^{1} \&$ Hesham Almujamed $^{1}$ \\ ${ }^{1}$ Accounting Department, College of Business Studies, The Public Authority for Applied Education and Training, \\ Kuwait \\ Correspondence: Faisal Alanezi, Accounting Department, College of Business Studies, the Public Authority for \\ Applied Education and Training, Kuwait. E-mail:alanezifs@hotmail.com
}

Received: February 9, 2014

Accepted: March 24, $2014 \quad$ Online Published: May 22, 2014

doi:10.5539/ijbm.v9n6p58

URL: http://dx.doi.org/10.5539/ijbm.v9n6p58

\begin{abstract}
This paper reports the results of an investigation into Kuwaiti multi-investors' perceptions of the different types of information useful for investment decision-making.

One hundred and sixty-eight useable questionnaires out of 410 with a response rate of $41 \%$ were collected. The questionnaire targeted key players in the Kuwaiti stock market-namely, analysts, fund managers, individual investors and stockbrokers who are involved with investment decisions.

The study found that the most important sources of information to the Kuwaiti multi-investors concerned "general corporate information was information about major types of product (services), and for "financial information," was operating profit. In addition, the most important item in "non-financial information" was new contracts won by the company. Furthermore, the most important item in "corporate governance information" was corporate strategies. Moreover, the most important item in "corporate social information" was improvement in customer services. Finally, the most important item in "type of valuation methods" was fundamental analysis. However, with the exception of some corporate information items, no significant differences were found between participants' perceptions. It can be inferred that all the related corporate information sources useful for investment decision-making used in this study are important to the all Kuwaiti stock exchange participants.
\end{abstract}

Keywords: investment decision, Kuwaiti multi-investors' perceptions, types of information, Kuwait Stock Exchange

\section{Introduction}

Investors need different types of information to help them make investment decisions. Providing required information about public corporations is essential to the growth and development of capital markets (Saudagaran, 2004). Indeed, if required information is not provided or not sufficient, potential investors may be hesitant to invest because they lack the necessary information to make investment decisions.

Kuwait is an emerging nation with a developing securities market with more than 200 shares listed on the Kuwait Stock Exchange (KSE) (KSE, 2013). With its economy heavily reliant on oil production and exportation, the Kuwaiti securities market provides channels for financing and investment in new businesses with a view toward diversifying its economy. Under pressure to diversify the economy and provide a measure of protection from the impact of volatile oil prices, the KSE has gradually commenced allowing foreign investment in its listed securities. Kuwait needs foreign investment to engender growth in its capital market and economy as a whole. Consequently, during the 1990s Kuwait underwent liberalization and privatization programs aimed at reducing governmental expenditure, widening the public investment base, increasing the number of investors, and encouraging private sector participation in shaping the economy and spurring it toward an open market. In this respect the 1999 Amiree Decree Law No. (10) regulating the direct investment for foreign capital of Kuwait was issued and an investment committee was assigned to study the investment requirements, promoting investment opportunities in the country and defining incentives to encourage foreign investors and facilitate licenses for projects by eliminating the obstacles investors may face. This Amiree Decree Law also provided guarantees for foreign investors by preserving ownership rights in their enterprises. To further encourage foreign investors to invest in Kuwait, the 2000 Amiree Decree Law No. (20) approved non-Kuwaitis' ownership in shares in Kuwaiti 
joint-stock companies. Foreign investors may thus own shares in existing Kuwaiti companies or acquire them in those that may be established in the future. Thus, it is expected that Kuwait will continue to attract the consideration of global investors (Almujamed, Fifield, \& Power, 2012).

The primary objective of disclosure research is to investigate whether the required information that companies produce provides investors and other users sufficient information to enable them to make informed decisions. The disclosure of accounting information is a major concern for investors, regulators, and other users of financial reports and is a popular study area for accounting researchers. Over the last 10 years, it has been a primary area of financial reporting research (Beaver, 2002). Accounting information is expected to provide investors and other users of financial statements useful information to help them make informed economic decisions.

The current study investigates the perceptions of different user groups regarding the essential sources of information about companies for making investment decisions. In addition, the global spread of the 2008 financial crisis should increase interest in the sources of information provided in developing countries, especially those whose activities (such an oil production) impact the global economy so greatly. Over the last two decades, the Kuwaiti government has attempted to encourage the growth of the economy and the development of the stock market in order to become internationally competitive. These goals require that essential information sources be available and sufficient to encourage investors to play an expected part in the growth of the Kuwaiti market and economy. Thus, evaluating that information is essential.

It is expected that the current study will deliver valuable insights and assistance to Kuwaiti regulators and preparers in improving corporate sources of information and, in turn, preparers could form their information sources to the needs of its users. This is essential in order for the corporations to keep current and attract more investments. In addition, regulators should encourage Kuwaiti's listed companies to shape their information sources more closely to meet the demands of users.

The rest of this study is organized as follows. Section 2 presents a review of the relevant literature. Section 3 describes the data collection procedures and statistical techniques used in this study. Section 4 introduces the research objectives. Section 5 reports the findings of this study and the final section offers a summary and conclusion and discusses the study's limitations and policy implications.

\section{Literature Review}

A number of research papers (Almujamed et al., 2012; Al Sawalqa, 2012; Alzarouni, Aljifri, Ng, \& Tahir, 2011; Zoysa \& Rudkin, 2010; Desoky, 2010; Abdelkarim, Shahin, \& Arqawi, 2009; Al-Ajmi, 2009; Alattar \& Al-Khater, 2007; Al-Tamimi, 2006; Al-Razeen \& Karbhari, 2004; Naser, Nuseibeh, \& Al-Hussaini, 2003; Bartlett \& Chandler, 1997; Abu-Nassar \& Rutherford, 1996; Scott \& Smith, 1992; Baker \& Haslem, 1973) have studied the different types of corporate information for investment decision-making. Results from some of the studies relevant to this one are discussed below.

In their pioneer study, Baker and Haslem (1973) investigated the degree of usage of various sources of corporate information in the United States. They found that individual investors relied on stockbrokers' advice as their main source of information for investment decision-making. Since then, corporate information related to investment decisions has attracted considerable attention.

In terms of investors' perceptions of various sources of corporate information pertaining to investment decisions, Scott and Smith (1992) found that newspapers, trade journals, other financial reports, advisory services, and direct contact with company officials were the most used sources of information.

Abu-Nassar and Rutherford (1996) used a questionnaire to investigate the perceptions of five groups of user of corporate financial reports in Jordan. These users were institutional shareholders, bank loan officers, stockbrokers, academics, and individual shareholders. They found that income statement, balance sheets, directors' reports, and statistical summary sections were read thoroughly by all of these user groups.

Along similar lines, Bartlett and Chandler (1997) in their study in UK used a questionnaire to ask respondents to indicate which other sources of information they read thoroughly or briefly. They found that financial press reports were the most widely read. Next in order of most read were full corporate annual reports, interim financial statements, summary annual financial statements, preliminary announcements, and stockbrokers' reports.

Similar claims were made by Naser et al. (2003), when they explored the perceptions of different user groups of financial information related to corporate reporting in Kuwait. These groups included institutional investors, individual investors, financial analysts, bank loan officers, government officials, auditors, and stock market brokers. Their research participants suggested that the information contained in the annual reports was important to make informed investment decisions. 
Al-Razeen and Karbhari (2004) examined the perceptions of the users of annual corporate reports in Saudi Arabia - namely, individual investors, institutional investors, creditors, government officials, and financial analysts. Their focus was on the use and importance of seven different sources of corporate information contained in Saudi annual reports, such as the board of directors' report, the auditors report, the balance sheet, the income statement, the statement of retained earnings, cash flow statements, and notes to the financial statements. Their results showed that the balance sheet and the income statement were the most important sections of the annual report to most of the Saudi user groups, while the board of directors' report was found to be the least popular. Furthermore, they noted that individual investors placed much less importance on the cash flow statement.

Mirshekary and Saudagaran (2005) examined the perceptions of Iranian user groups, comprising bank loan officers, bank investment officers, auditors, tax officers, stockbrokers, institutional investors, and academics, regarding corporate annual reports. They found that the majority of respondents indicated the annual report was the most important source of information. Respondents ranked cost of goods sold, total revenue and sources of revenue, breakdown of operating income, and extraordinary gains or losses as their top three required information items.

Alattar and Al-Khater (2007) explored in depth users' views on corporate annual reports in Qatar. The questionnaire sample included five major user groups - namely, individual investors, institutional investors, bank credit officers, government officers, and financial analysts. Their results were not different from previous studies, as annual reports were considered the main source of information for investment decisions. Respondents also rated the balance sheet, auditors report, cash flow statement, income statement, and notes to the accounts as the most important sections in annual reports. In addition, respondents considered government publications, newspapers, magazines, and journals to be very important sources of up-to-date, useful, and easy to access information. Respondents differed significantly in their perceptions about the importance of the cash flow section, the use of accounting information for monitoring investment decisions, and the use of other available sources of information.

In a related study, Abdelkarim et al. (2009) investigated the perception of users of information disclosed in the financial reports of companies listed on the Palestine Securities Exchange. Five user groups were surveyed: individual and institutional investors, bank credit officers, academics, and stock market brokers. They found that external users attached a higher level of importance to the profit and loss statement, balance sheet, and cash flow statement.

Al-Ajmi (2009) in his study in Bahrain collected data through a questionnaire survey that revealed that annual reports were the most important source of information for in making investment decisions. This was followed by personal expectations, advice from consultants, advice from bankers, newspapers, advice from stockbrokers, advice from friends, and rumours from the market, respectively.

Zoysa and Rudkin (2010) investigated how users of company annual reports in Sri Lanka view those reports. The data reported in this study were collected through a questionnaire survey, covering seven user groups: accountants, executives, bankers, tax officers, academics, financial analysts, and investors. They found that the majority of users view annual reports as the most important source of company information.

Desoky (2010) in his study in Egypt found that individual investors considered electronic sources of financial information as the most important, followed by specialized newspapers and magazines, and corporate annual reports, respectively.

Alzarouni et al. (2011) examined the usefulness of financial reports to users in the United Arab Emirates (UAE). A questionnaire was distributed to major external users of financial reports. They indicated that users in the UAE consider corporate annual reports to be the most important source of information.

In a recent study, Al Sawalqa (2012) examined the importance of different Jordanian corporate financial information sources in investment decision-making. Ninety-four Jordanian individual investors were surveyed. He found that Jordanian individual investors ranked corporate annual reports as the most important source of information for the purpose of their investment decision-making. This was followed by published daily share prices, corporate Web sites, newspapers and magazines, advice of friends, discussion with company staff, stockbrokers' advice, and tips and rumours, respectively.

More recently, Almujamed et al. (2012) examined the share valuation methods and sources of information employed by Kuwaiti investors, using a questionnaire survey. They found that Kuwaiti investors behave like their counterparts in developed and emerging stock markets; fundamental analysis is the main appraisal technique used by investors; technical analysis and risk analysis are ranked second and third respectively. Furthermore, quarterly 
and annual corporate reports as well as newspapers, the KSE Web site, and charts are commonly studied by investors when valuing Kuwaiti shares. By contrast, discussion with a company's management was not common since executives were usually not willing to discuss their firm's performance with investors.

Overall, the above prior studies reveal varied results. The inconsistent outcomes with regard to the information sources useful to the investment decision could be due to the fact that the previous studies were conducted in different developed and developing countries at different times and among different types of investors. In addition, the previous studies used a limited number of information sources and put more emphasis on financial information sources in providing different types of investors with the information necessary to make the best investment decisions.

This review of prior studies shows that only two studies (Almujamed et al., 2012; Naser et al., 2003) discussed financial information sources and investment decision-making in Kuwait. The current study is different from these two studies. This study included a broad range of information sources useful for investment decision-making. Furthermore, this study is comprehensive because it investigates Kuwait stock market participants' perceptions of a broad set of corporate information sources - general, financial, nonfinancial, social, corporate governance, and type of valuation methods - useful for investment decisions making. Furthermore, previous research in the field (e.g., Abu-Nassar \& Rutherford, 1996; Al-Attar \& Al-Khater, 2007; Al Sawalqa, 2012; Almujamed et al., 2012) has shown that different types of investors have used many sources of information; across these studies, no one source was found to be the best or most important source for investors. Therefore, it can be inferred that all the related corporate information sources are useful for investment decision-making.

\section{Research Objectives}

The purpose of this paper is to report the results of an investigation into Kuwaiti multi-investors' perceptions of different types of information useful to investment decision-making. To do so, the research tries to answer the following questions:

* What are the most important sources of information related to investment decisions in Kuwait?

* Are there any significant differences between users groups on the importance of the information needed to make investment decisions?

* Are there any significant differences between users groups on the importance of general information needed to make investment decisions?

* Are there any significant differences between users groups on the importance of financial information needed to make investment decisions?

* Are there any significant differences between users groups on the importance of nonfinancial information needed to make investment decisions?

* Are there any significant differences between users groups on the importance of social information needed to make investment decisions?

* Are there any significant differences between users groups on the importance of corporate governance information needed to make investment decisions?

* Are there any significant differences between users groups on the importance of type of valuation methods needed to make investment decisions?

\section{Methodology}

\subsection{Data Collection and Sample}

A questionnaire was developed from previous literature that has investigated the multi-investors' perceptions of information useful for investment decision-making (Abu-Nassar \& Rutherford, 1996; Bartlett \& Chandler, 1997; Alattar \& Al-Khater, 2007; Abdelkarim et al., 2009; Almujamed et al., 2012). Thus, the data reported in this study were collected through a questionnaire survey. A draft of the questionnaire was reviewed several times and then piloted and distributed to a group of different users (three analysts, two fund managers, and four individual investors). Based on their comments and suggestions, the questionnaire was then modified several times to develop the final version of the questionnaire.

As one of the main objectives of this study is to investigate the perceptions of different user groups regarding the most important and essential source of information about companies used in making investment decisions, it was important to include all primary users in the current research. Thus, the questionnaire targeted key players in the Kuwaiti stock market: analysts, fund managers, individual investors, and stockbrokers. The choice of these target 
groups was influenced by the literature as well as responses from the pilot questionnaire.

Table 1 shows that 168 out of 410 questionnaires (a response rate of $41 \%$ ) were useable and collected. These are analysed in the reminder of the paper (see Part A of Table 1) (Note 1). Part B of Table 1 shows that $32.1 \%$ of the respondents were individual investors. This result is not surprising as access to individual investors in the trading hall of the KSE was easier than to that of other groups of participants.

Table 1. Respondents to the questionnaire survey

\begin{tabular}{|c|c|c|c|c|c|c|c|c|c|c|}
\hline \multirow[t]{2}{*}{ Part A : Position } & \multicolumn{3}{|c|}{ Distributed Questionnaire } & \multicolumn{3}{|c|}{ Responses } & & \multicolumn{3}{|c|}{ Useable Responses } \\
\hline & \multicolumn{2}{|c|}{ No. } & \multicolumn{2}{|l|}{$\%$} & No. & \multicolumn{2}{|l|}{$\%$} & No. & \multicolumn{2}{|c|}{$\%$} \\
\hline Fund Mangers & \multicolumn{2}{|l|}{70} & \multicolumn{2}{|l|}{100.0} & 40 & \multicolumn{2}{|l|}{57.2} & 34 & \multicolumn{2}{|c|}{85.0} \\
\hline Individual Investors & \multicolumn{2}{|l|}{150} & \multicolumn{2}{|l|}{100.0} & 70 & 46.6 & & 54 & \multicolumn{2}{|c|}{77.0} \\
\hline Analysts & \multicolumn{2}{|l|}{90} & \multicolumn{2}{|l|}{100.0} & 55 & 61.1 & & 43 & \multicolumn{2}{|c|}{78.0} \\
\hline Stockbrokers & \multicolumn{2}{|l|}{50} & \multicolumn{2}{|l|}{100.0} & 40 & 80.0 & & 37 & \multicolumn{2}{|c|}{92.5} \\
\hline Others & \multicolumn{2}{|l|}{50} & \multicolumn{2}{|l|}{100.0} & 50 & 100.0 & & 0 & \multicolumn{2}{|c|}{0.0} \\
\hline Total & \multicolumn{2}{|l|}{410} & \multicolumn{2}{|l|}{100.0} & 255 & 62.2 & & 168 & & \\
\hline Part: B & & & & & & & & & & \\
\hline & All & icipants & FM & & IV & & $\mathrm{AN}$ & & SB & \\
\hline Statement & No. & $\%$ & No. & $\%$ & No. & $\%$ & No. & $\%$ & No. & $\%$ \\
\hline $\begin{array}{l}\text { Total number of respons } \\
\text { relative to } 168 \text { useable } \\
\text { responses }\end{array}$ & 168 & 100.0 & 34 & 20.2 & 54 & 32.1 & 43 & 25.6 & 37 & 22.1 \\
\hline
\end{tabular}

Note. This table shows the responses to the questionnaire survey based on such participant's job. Part A reports the number and percentage of distributed and useable responses in the questionnaire survey while Part B indicates the number and the percentage of responses useable based on participant's job. The participants include Fund Mangers (FM); (ii) Individual Investors (IV); (iii) Analysts (AN); and (iv) Stockbrokers (SB); Others relates to employees of the KSE and Kuwait Clearing House.

\subsection{Reliability Analysis}

To assess the reliability and internal consistency of the research instrument of Part 2 of the questionnaire, a common measure of scale reliability called Cronbach's alpha was used. Cronbach's alpha takes a value between 0 and 1 , where 1 indicates perfect correlation between the parts of instrument, while 0 indicates no correlation between these parts. According to Nunnally (1978) and DeVellis (2003), a Cronbach's alpha coefficient of 0.5 or higher is considered an acceptable indication of construct reliability. In this study, the Cronbach's alpha was calculated for each category of information as well as for all of the items included in all categories. The overall Cronbach's alpha coefficient for all categories was 0.985 , indicating the overall reliability of the questionnaire. The Cronbach's alpha coefficient for the six categories - namely, general corporate information, financial information, nonfinancial information, corporate governance information, corporate social information, and type of valuation methods - was (0.785), (0.812), (0.579), (0.879), (0.869), and (0.638) respectively. The Cronbach's alpha coefficient for the six categories showed that these categories were reliable.

\subsection{Descriptive Analysis}

Table 2 provides background information on the research participants. Statistics show that the participant groups held at least a professional qualification, with $1.2 \%$ having a doctorate degree, $20.8 \%$ a masters degree, $57.7 \%$ a bachelors degree, and $20.3 \%$, another professional qualification. These qualification statistics show that most of the respondents were highly educated. Fund managers and analysts were the most highly educated groups; a majority of them had at least a bachelor degree while a considerable minority held a masters and doctorate degree. Such findings may suggest that fund managers and analysts were more knowledgeable about investments analysis. In terms of experience, $20.7 \%$ had less than five years of experience, $36 \%$ had $5-10$ years of experience, and $43.3 \%$ had more than 10 years of experience. A majority of the participants $(79.3 \%)$ had more than five years of experience in investments activities; this would suggest that the respondents were knowledgeable about the research area and that their opinions are worth examining. 
Table 2. Background information of participants

\begin{tabular}{|c|c|c|c|c|c|c|c|c|c|c|c|}
\hline \multirow[t]{2}{*}{ Statements } & \multirow{2}{*}{$\begin{array}{l}\text { Choice of } \\
\text { Answer }\end{array}$} & \multicolumn{2}{|l|}{ All } & \multicolumn{2}{|l|}{ FM } & \multicolumn{2}{|l|}{ IV } & \multicolumn{2}{|l|}{ AN } & \multicolumn{2}{|l|}{ SB } \\
\hline & & No. & $\%$ & No. & $\%$ & No. & $\%$ & No. & $\%$ & No. & $\%$ \\
\hline Education & Less than & 4 & 2.4 & 0 & 0.0 & 2 & 3.7 & 1 & 2.3 & 1 & 2.7 \\
\hline \multirow[t]{5}{*}{ Qualifications } & Diploma & & & & & & & & & & \\
\hline & Diploma & 30 & 17.9 & 2 & 5.9 & 9 & 16.6 & 2 & 4.7 & 17 & 46.0 \\
\hline & Bachelors & 97 & 57.7 & 18 & 53.0 & 34 & 63.0 & 30 & 69.8 & 15 & 40.5 \\
\hline & Master & 35 & 20.8 & 13 & 38.2 & 8 & 14.8 & 10 & 23.2 & 4 & 10.8 \\
\hline & Doctorate & 2 & 1.2 & 1 & 2.9 & 1 & 1.9 & 0 & 0.0 & 0 & 0.0 \\
\hline \multirow[t]{3}{*}{$\begin{array}{l}\text { Years of } \\
\text { Experience }\end{array}$} & $\begin{array}{l}\text { Less than } 5 \\
\text { years }\end{array}$ & 34 & 20.7 & 5 & 14.7 & 15 & 28.9 & 6 & 14.0 & 8 & 22.9 \\
\hline & $\begin{array}{l}\text { Between } 5 \text { and } \\
10 \text { years }\end{array}$ & 59 & 36.0 & 13 & 38.2 & 14 & 26.9 & 21 & 48.8 & 11 & 31.4 \\
\hline & $\begin{array}{l}\text { More than } 10 \\
\text { years }\end{array}$ & 71 & 43.3 & 16 & 47.1 & 23 & 44.2 & 16 & 37.2 & 16 & 45.7 \\
\hline
\end{tabular}

Note. The table presents background details for the research participants. Specifically, it reports statistics on the education qualification and experience of the respondents. The percentage of these frequencies are based on the number of responses relative to the total number of questionnaires with replies for each statement; 168 and 164 answers were available for education qualification and years of experience respectively.

Details on the level and type of investment undertaken by participants were also ascertained and the responses summarized in Table 3. In terms of the amount of money invested, $15.6 \%$ are investing less than KD 10,000, $26.2 \%$ are investing between KD 10,000-50,000), 27.9\% between KD 50,000-500,000, $14.7 \%$ between KD (500,000-5 million, and $15.6 \%$ invested more than KD 5 million. This is an indication that big investors dominate the market. Also, this table indicates that fund managers invested larger sums in the KSE as compared with other groups of participants; this result is expected since they administer funds on behalf of clients. In addition, Table 3 shows that $43.7 \%$ of respondents invested for long-term horizons of more than two years. Such findings may suggest that investors were aware of risk associated with speculation or may hold stocks that have declined more than two years in the hope of a rebound. Finally, most of the participants consider shares from a specific industry, notably $43.5 \%$ focus on the services industry.

Table 3. Investment characteristics of participants respondents

\begin{tabular}{|c|c|c|c|c|c|c|c|c|c|c|c|}
\hline \multirow{2}{*}{ Statements } & \multirow{2}{*}{ Choice of Answer } & \multicolumn{2}{|l|}{ All } & \multicolumn{2}{|l|}{ FM } & \multicolumn{2}{|l|}{ IV } & \multicolumn{2}{|l|}{ AN } & \multicolumn{2}{|l|}{ SB } \\
\hline & & No. & $\%$ & No. & $\%$ & No. & $\%$ & No. & $\%$ & No. & $\%$ \\
\hline \multirow{5}{*}{$\begin{array}{l}\text { Average amount of money } \\
\text { invested }\end{array}$} & Less than $\mathrm{KD} 10,000$ & 19 & 15.6 & 2 & 6.7 & 7 & 15.9 & 7 & 22.6 & 3 & 17.6 \\
\hline & From KD10,000 to KD 50,000 & 32 & 26.2 & 0 & 0.0 & 20 & 45.4 & 8 & 25.8 & 4 & 23.6 \\
\hline & From KD 50,000 to $\mathrm{KD} 500,000$ & 34 & 27.9 & 13 & 43.3 & 9 & 20.5 & 7 & 22.6 & 5 & 29.4 \\
\hline & From KD 500,000 to KD 5.0 Million & 18 & 14.7 & 7 & 23.3 & 5 & 11.4 & 4 & 12.9 & 2 & 11.8 \\
\hline & More than KD 5.0 Million & 19 & 15.6 & 8 & 26.7 & 3 & 6.8 & 5 & 16.1 & 3 & 17.6 \\
\hline \multirow[t]{3}{*}{ Average Holding Period } & Less than 12 months & 27 & 22.7 & 6 & 20.0 & 11 & 26.8 & 6 & 19.4 & 4 & 23.5 \\
\hline & 13-24 months & 40 & 33.6 & 9 & 30.0 & 16 & 39.0 & 8 & 25.8 & 7 & 41.2 \\
\hline & More than 24 months & 52 & 43.7 & 15 & 50.0 & 14 & 34.2 & 17 & 54.8 & 6 & 35.3 \\
\hline \multirow[t]{8}{*}{ Sector focus on* } & Banking & 1 & 0.6 & 0 & 0.0 & 1 & 1.9 & 0 & 0.0 & 0 & 0.0 \\
\hline & Investment & 3 & 1.8 & 0 & 0.0 & 2 & 3.7 & 0 & 0.0 & 0 & 0.0 \\
\hline & Insurance & 1 & 0.6 & 0 & 0.0 & 0 & 0.0 & 0 & 0.0 & 0 & 0.0 \\
\hline & Real Estate & 16 & 9.4 & 3 & 8.8 & 6 & 11.1 & 19 & 16.7 & 2 & 5.4 \\
\hline & Industrial & 10 & 5.9 & 3 & 8.8 & 4 & 7.4 & 30 & 26.3 & 1 & 2.7 \\
\hline & Service & 74 & 43.5 & 14 & 41.2 & 26 & 48.1 & 19 & 16.7 & 12 & 32.5 \\
\hline & Food & 24 & 14.1 & 7 & 20.6 & 8 & 14.8 & 29 & 25.4 & 4 & 10.8 \\
\hline & Non-Kuwait & 41 & 24.1 & 7 & 20.6 & 7 & 13.0 & 17 & 14.9 & 18 & 48.6 \\
\hline
\end{tabular}

Note. The table shows the investment characteristics of the research participants. Specifically, it reports the average amount invested in, average holding period for a share and the area of investment focus; these responses were available for 122, 119 and 168 participants for these questions respectively. An * indicates that participant focuses on more than sector. 


\section{Results}

Respondents were asked to indicate how important they considered different sources of information when making investment decisions. A five-point Likert scale was used, ranging from $1=$ "Strongly disagree" to $5=$ "Strongly agree." Table 4 shows the frequency distribution of each item and its rank according to the degree that Kuwait stock market participants believe they are useful to investment decisions.

To rank the items, first we recorded each question into positive, negative, and undecided (neutral) answers. Then we considered only positive attitude questions (which have the largest means), which show a consistent pattern for all questions. Having selected positive attitude, then we ranked them per dimension, as shown in Table 4. Along the same line, we ranked the average rank of each group according to their relative importance to indicate their importance from respondents' standpoint.

Table 4 shows that the first three important items for the first category of source of information, namely general corporate information were information about major types of products (services), information about the industry, and organization structure. Also, the table shows that the items ranked as most important in the second category; namely, financial information, were operating profit, total assets, total debt, cash flow statement, and share price information. These results are consistent with the findings of Al Sawalga (2012) and Almujamed et al. (2012), who found, for example, that historical data from share prices is informative data as it tells the highest, lowest, support, and resistance levels for technical analysis when making investment decisions.

In addition, Table 4 indicates that the items ranked as most important in the third category, namely, nonfinancial information, were new contracts won by the company, company expansion, launching of a new project, takeover decisions, and auditors report. This result is similar to that of Alattar and Al-Khater (2007), who found that the auditors report is one of the main sources of information for investment decisions, suggesting that the auditors report provides sound accounting information.

Moreover, Table 4 identifies the most important items of information in the fourth category, namely, corporate governance information were corporate strategies, change in chairman or board member/large shareholder, positions held by executive directors, and background of senior management. Such information helps investors track the history of the executive teams for companies.

Furthermore, this table indicates that the items ranked as most important for the fifth category, corporate social information, were improvement in customer services, improvement in product quality, distribution of marketing network for products, and number of employees. This finding highlights the importance of corporate social information for KSE participants.

Finally, the table shows that the most important sources of information in the sixth category, type of valuation methods, were fundamental analysis, risk analysis, and technical analysis respectively. This result is consistent with a study conducted by Almujamed et al. (2012), who found fundamental analysis is the main appraisal technique used by investors.

Table 4. Frequency distribution of the items that Kuwait stock market participants' believe is useful to the investment decision for each category of information sources used in this research

\begin{tabular}{|c|c|c|c|c|}
\hline Item & Frequency & Rank & $\begin{array}{l}\text { Relative } \\
\text { frequency }\end{array}$ & $\begin{array}{l}\text { Group average } \\
\text { rank }\end{array}$ \\
\hline A-General Corporate Information & & & & 3.333 \\
\hline Year of listing at Kuwait Stock Exchange (KSE) & 109 & 4 & 64.9 & \\
\hline Listed in foreign stock market & 94 & 6 & 56.3 & \\
\hline Organization structure & 111 & 3 & 66.9 & \\
\hline Information about the industry & 151 & 2 & 89.9 & \\
\hline Corporate establishment's date & 109 & 4 & 64.9 & \\
\hline Information about major type of product (services) & 152 & 1 & 91.0 & \\
\hline B- Financial information & & & & 5.820 \\
\hline Cash flow Statement & 150 & 4 & 90.9 & \\
\hline Profit and Loss Account & 146 & 7 & 88.0 & \\
\hline Operating Profit & 154 & 1 & 92.2 & \\
\hline Non -operating profit & 128 & 11 & 77.1 & \\
\hline Realized and unrealized earnings & 147 & 6 & 88.0 & \\
\hline Financial Ratios & 132 & 10 & 80.0 & \\
\hline
\end{tabular}




\begin{tabular}{|c|c|c|c|c|}
\hline Share Prices Information & 149 & 5 & 89.8 & \\
\hline Volume of Shares Traded & 146 & 7 & 88.0 & \\
\hline Total Assets & 151 & 2 & 90.4 & \\
\hline Total Debt & 151 & 2 & 90.4 & \\
\hline Total of owners' equity & 145 & 9 & 87.3 & \\
\hline C-Non financial information & & & & 6.000 \\
\hline Friend's advice & 52 & 11 & 31.1 & \\
\hline News papers & 103 & 8 & 61.7 & \\
\hline Kuwait Stock Exchange Websites & 112 & 7 & 67.1 & \\
\hline Insider information & 124 & 6 & 74.3 & \\
\hline Tips and rumors & 86 & 10 & 51.5 & \\
\hline Chairman's statement & 92 & 9 & 55.4 & \\
\hline Auditor's report & 128 & 5 & 76.6 & \\
\hline Company expansion & 143 & 2 & 85.6 & \\
\hline A takeover decision & 131 & 4 & 78.9 & \\
\hline Any new contract won by the company & 145 & 1 & 87.3 & \\
\hline The launch of a new project & 138 & 3 & 83.1 & \\
\hline D-Corporate Governance Information & & & & 4.500 \\
\hline Academic qualification of board of directors & 109 & 5 & 65.7 & \\
\hline Position held by executive directors & 125 & 3 & 74.9 & \\
\hline Background of senior management & 122 & 4 & 73.5 & \\
\hline Director's remuneration & 90 & 7 & 54.2 & \\
\hline Board's directorship of other companies & 103 & 6 & 61.7 & \\
\hline Age of directors & 80 & 8 & 48.2 & \\
\hline Corporate strategies & 143 & 1 & 86.1 & \\
\hline A change in chairman or board member/large shareholder & 127 & 2 & 76.0 & \\
\hline E- Corporate Social Information & & & & 4.890 \\
\hline Participation in government social campaigns & 88 & 7 & 52.4 & \\
\hline Community programs (health \& education) & 88 & 7 & 52.4 & \\
\hline Recruitment policy & 94 & 5 & 56.0 & \\
\hline Number of employees & 103 & 4 & 61.3 & \\
\hline Percentage of foreign and national labor force & 91 & 6 & 54.2 & \\
\hline Improvement in product quality & 144 & 2 & 85.7 & \\
\hline Improvement in customer services & 145 & 1 & 86.3 & \\
\hline Information of donations to charitable organizations & 86 & 9 & 51.2 & \\
\hline Distribution of marketing network of products & 130 & 3 & 77.4 & \\
\hline \multicolumn{5}{|l|}{ F-Type of Valuation Methods } \\
\hline Technical Analysis & 141 & 3 & 83.9 & 2.000 \\
\hline Fundamental Analysis & 159 & 1 & 94.6 & \\
\hline Risk Analysis & 149 & 2 & 89.2 & \\
\hline
\end{tabular}

Note. Average group rank is the regular average of all ranks of the group. Frequency: total frequency to sample size.Relative frequency is the percentage of frequency.

Table 5 lists all types of information source used in this study and their rank, based on their frequency distribution. Analysis of this table shows respondents perceived that fundamental analysis, operating profit, information about major types of products (services), information about the industry, total assets, total debt, cash flow statement, share price information, and risk analysis were the most frequently used sources of information; their frequency distribution were $160,155,153,152,152,152,151,150$, and 150, respectively. These results are consistent with results of previous studies from different emerging markets (Alattar \& Al-Khater, 2007; Abdelkarim et al., 2009; Al Sawalqa, 2012; Almujamed et al., 2012).

Profit and loss accounts, realized and unrealized earnings, volume of shares traded, total of owners' equity, new contracts won by the company, and improvement in customer services were also important sources of information useful to the investment decision but less frequently used among the research participants; they had frequency distributions that ranged from 147 to 145. This result is similar to that of Abu-Nassar and Rutherford (1996), who gave less weight to such information. 
On the contrary, friends' advice, ages of directors, tips and rumours, and donations to charitable organizations were seen as the least-used sources of information for making investment decisions. Such findings were not different from Almujamed et al. (2012), as investors tend to do their homework by doing some analysis before making any investment decision.

Table 5. Frequency distribution of the items that Kuwait stock market participants believe is useful to the investment decision for all items of source of information used in this study

\begin{tabular}{|c|c|c|c|}
\hline Item & Frequency & Rank & $\%$ \\
\hline Fundamental Analysis & 159 & 1 & 94.6 \\
\hline Operating Profit & 154 & 2 & 91.6 \\
\hline Information about major type of product (services) & 152 & 3 & 90.5 \\
\hline Information about the industry & 151 & 4 & 89.9 \\
\hline Total Assets & 151 & 4 & 89.9 \\
\hline Total Debt & 151 & 4 & 89.9 \\
\hline Cash flow Statement & 150 & 7 & 89.3 \\
\hline Share Prices Information & 149 & 8 & 88.7 \\
\hline Risk Analysis & 149 & 8 & 88.7 \\
\hline Realized and unrealized earnings & 147 & 10 & 87.5 \\
\hline Profit and Loss Account & 146 & 11 & 86.9 \\
\hline Volume of Shares Traded & 146 & 11 & 86.9 \\
\hline Total of owners' equity & 145 & 13 & 86.3 \\
\hline Any new contract won by the company & 145 & 13 & 86.3 \\
\hline Improvement in customer services & 145 & 13 & 86.3 \\
\hline Improvement in product quality & 144 & 16 & 85.7 \\
\hline Company expansion & 143 & 17 & 85.1 \\
\hline Corporate strategies & 143 & 17 & 85.1 \\
\hline Technical Analysis & 141 & 19 & 83.9 \\
\hline The launch of a new project & 138 & 20 & 82.1 \\
\hline Financial Ratios & 132 & 21 & 78.6 \\
\hline A takeover decision & 131 & 22 & 78.0 \\
\hline Distribution of marketing network of products & 130 & 23 & 77.4 \\
\hline Non-operating profit & 128 & 24 & 76.2 \\
\hline Auditor's report & 128 & 24 & 76.2 \\
\hline A change in chairman or board member/large shareholder & 127 & 26 & 756 \\
\hline Position held by executive directors & 125 & 27 & 74.4 \\
\hline Insider information & 124 & 28 & 73.8 \\
\hline Background of senior management & 122 & 29 & 72.6 \\
\hline Kuwait Stock Exchange Websites & 112 & 30 & 66.7 \\
\hline Organization structure & 111 & 31 & 66.1 \\
\hline Year of listing at Kuwait Stock Exchange (KSE) & 109 & 32 & 64.9 \\
\hline Corporate establishment's date & 109 & 32 & 64.9 \\
\hline Academic qualification of board of directors & 109 & 32 & 64.9 \\
\hline News papers & 103 & 35 & 61.3 \\
\hline Board's directorship of other companies & 103 & 35 & 61.3 \\
\hline Number of employees & 103 & 35 & 61.3 \\
\hline Listed in foreign stock market & 94 & 38 & 56.0 \\
\hline Recruitment policy & 94 & 38 & 56.0 \\
\hline Chairman's statement & 92 & 40 & 54.8 \\
\hline Percentage of foreign and national labor force & 91 & 41 & 54.2 \\
\hline Director's remuneration & 90 & 42 & 53.6 \\
\hline Participation in government social campaigns & 88 & 43 & 52.4 \\
\hline Community programs (health \& education) & 88 & 43 & 52.4 \\
\hline Tips and rumors & 86 & 45 & 51.2 \\
\hline Information of donations to charitable organizations & 86 & 45 & 51.2 \\
\hline Age of directors & 80 & 47 & 47.6 \\
\hline Friend's advice & 52 & 48 & 31.0 \\
\hline
\end{tabular}

Note. Frequency: total frequency to sample size. 


\subsection{Kuwait Stock Market Participants' Perceptions of "General Corporate Information"}

Table 6 provides summary statistics for Kuwait stock market participants' perceptions of general corporate information useful to investment decisions. As shown, we have tested each statement against Kuwait stock market participants' perceptions using the nonparametric Kruskal-Wallis test. As indicated, no significant differences between participants' perceptions were found except for the statement "information about major types of product (services)" where the (p-value 0.029) reveals significant differences between participants, although all have positive perceptions of the statement.

Table 6. Kuwait stock market participants' perceptions of general corporate information useful to the investment decision

\begin{tabular}{|c|c|c|c|c|c|c|c|c|c|}
\hline \multirow{2}{*}{ Statements } & \multicolumn{2}{|c|}{ FM } & \multicolumn{2}{|c|}{ IV } & \multicolumn{2}{|c|}{ AN } & \multicolumn{2}{|c|}{ SB } & \multirow[t]{2}{*}{ P-value } \\
\hline & Mean & SD & Mean & SD & Mean & SD & Mean & SD & \\
\hline $\begin{array}{l}\text { Year of listing at Kuwait Stock } \\
\text { Exchange (KSE) }\end{array}$ & 3.59 & 1.44 & 3.69 & 1.21 & 3.72 & 1.14 & 3.81 & 0.88 & 0.878 \\
\hline Listed in foreign stock market & 3.41 & 1.28 & 3.32 & 1.21 & 3.49 & 1.21 & 3.97 & 0.96 & 0.134 \\
\hline Organization structure & 3.65 & 1.13 & 4.04 & 0.98 & 3.70 & 1.17 & 3.94 & 0.86 & 0.416 \\
\hline Information about the industry & 4.53 & 0.79 & 4.22 & 0.88 & 4.51 & 0.63 & 4.22 & 0.89 & 0.168 \\
\hline Corporate establishment's date & 3.82 & 0.97 & 3.68 & 1.12 & 3.98 & 1.17 & 4.05 & 0.94 & 0.276 \\
\hline $\begin{array}{l}\text { Information about major types of } \\
\text { product (services) }\end{array}$ & 4.74 & 0.57 & 4.26 & 0.95 & 4.49 & 0.59 & 4.24 & 0.90 & $* 0.029$ \\
\hline
\end{tabular}

Note. This table reports the Likert-Scale for questions about the perceptions of general corporate information from the prospect of research participants. A five-point Likert-Scale was used ranging from $1=$ 'Strongly disagree' to $5=$ 'Strongly agree. The participants include Fund Mangers (FM); (ii) Individual Investors (IV); (iii) Analysts (AN); and (iv) Stockbrokers (SB). This information is presented: (i) for all participants and individual groups. Finally, the $p$ - value for a test of equality of means across 4 different groups is provided (FM, IV, AN, SB).

\subsection{Kuwait Stock Market Participants' Perceptions of "Financial Information"}

Table 7 provides summary statistics for Kuwait stock market participants' perceptions of financial information useful to investment decisions. As shown, we have tested each statement against Kuwait stock market participants using the nonparametric Kruskal-Wallis test. As indicated, no significant differences between participants' perceptions were found except for the statement "realized and unrealized earnings," where the (p-value 0.006) reveals significant differences between all participants.

Table 7. Kuwait stock market participants' perceptions of financial information useful to the investment decision

\begin{tabular}{|c|c|c|c|c|c|c|c|c|c|}
\hline \multirow{2}{*}{ Statements } & \multicolumn{2}{|c|}{ FM } & \multicolumn{2}{|c|}{ IV } & \multicolumn{2}{|c|}{ AN } & \multicolumn{2}{|c|}{ SB } & \multirow[t]{2}{*}{ P-value } \\
\hline & Mean & SD & Mean & SD & Mean & SD & Mean & SD & \\
\hline Cash Flow Statement & 4.47 & 0.62 & 4.35 & 0.72 & 4.65 & 0.57 & 4.41 & 0.69 & 0.224 \\
\hline Profit and Loss Account & 4.24 & 0.78 & 4.37 & 0.72 & 4.49 & 0.70 & 4.49 & 0.65 & 0.479 \\
\hline Operating Profit & 4.59 & 0.50 & 4.34 & 0.71 & 4.56 & 0.70 & 4.35 & 0.72 & 0.245 \\
\hline Non-Operating Profit & 4.06 & 0.78 & 4.00 & 0.93 & 4.12 & 0.85 & 3.97 & 0.96 & 0.645 \\
\hline Realised and Unrealized Earnings & 4.68 & 0.48 & 4.28 & 0.75 & 4.19 & 0.85 & 4.35 & 0.75 & $* 0.006$ \\
\hline Financial Ratios & 4.21 & 0.81 & 4.00 & 0.96 & 4.23 & 0.68 & 4.11 & 0.84 & 0.475 \\
\hline Share Prices Information & 4.62 & 0.65 & 4.26 & 0.71 & 4.42 & 0.70 & 4.50 & 0.66 & 0.122 \\
\hline Volume of Shares Traded & 4.41 & 0.78 & 4.33 & 0.79 & 4.19 & 0.91 & 4.49 & 0.65 & 0.546 \\
\hline Total Assets & 4.44 & 0.75 & 4.45 & 0.78 & 4.44 & 0.63 & 4.43 & 0.65 & 0.917 \\
\hline Total Debt & 4.41 & 0.96 & 4.60 & 0.69 & 4.53 & 0.67 & 4.57 & 0.60 & 0.759 \\
\hline Total of Owners' Equity & 4.35 & 1.07 & 4.65 & 0.56 & 4.26 & 0.82 & 4.30 & 0.74 & 0.072 \\
\hline
\end{tabular}

Note. This table reports the Likert-Scale for questions about the perceptions of financial information from the prospect of research participants. A five-point Likert-Scale was used ranging from 1 = 'Strongly disagree' to 5 = 'Strongly agree. The participants include Fund Mangers (FM); (ii) Individual Investors (IV); (iii) Analysts (AN); and (iv) Stockbrokers (SB). This information is presented: (i) for all participants and individual groups. Finally, the $p$ - value for a test of equality of means across 4 different groups is provided (FM, IV, AN, SB). 


\subsection{Kuwait Stock Market Participants' Perceptions of "Nonfinancial Information"}

Table 8 provides summary statistics for Kuwait stock market participants' perceptions of nonfinancial information useful to investment decisions. A Kruskal-Wallis test found that no significant differences between participants' perceptions were found except for two statements "newspapers" and "auditor's report" where their (p-values 0.012 and 0.028 ) respectively, indicate significant differences between some groups of participants, although all have positive perceptions toward those two statements.

Table 8. Kuwait stock market participants' perceptions of non-financial information useful to the investment decision

\begin{tabular}{|c|c|c|c|c|c|c|c|c|c|}
\hline \multirow[t]{2}{*}{ Statements } & \multicolumn{2}{|c|}{ FM } & \multicolumn{2}{|c|}{ IV } & \multicolumn{2}{|c|}{ AN } & \multicolumn{2}{|c|}{ SB } & \multirow[t]{2}{*}{ P-value } \\
\hline & Mean & $\mathrm{SD}$ & Mean & SD & Mean & SD & Mean & $\mathrm{SD}$ & \\
\hline Friend's advice & 3.06 & 1.13 & 3.20 & 1.05 & 3.16 & 0.99 & 3.22 & 1.02 & 0.870 \\
\hline Newspapers & 3.65 & 0.77 & 3.50 & 0.86 & 3.86 & 0.83 & 4.00 & 0.72 & $* 0.012$ \\
\hline Kuwait Stock Exchange Website & 3.88 & 0.91 & 3.61 & 0.96 & 3.93 & 0.99 & 4.00 & 0.96 & 0.195 \\
\hline Insider information & 4.09 & 0.93 & 4.00 & 0.97 & 3.98 & 0.96 & 4.03 & 0.78 & 0.847 \\
\hline Tips and rumours & 3.38 & 1.35 & 3.41 & 1.19 & 3.33 & 1.23 & 3.72 & 1.19 & 0.571 \\
\hline Chairman's statement & 3.47 & 1.21 & 3.55 & 1.08 & 3.44 & 1.01 & 3.83 & 0.88 & 0.562 \\
\hline Auditor's report & 4.35 & 0.65 & 3.78 & 0.91 & 3.91 & 1.02 & 4.08 & 0.81 & *0.028 \\
\hline Company expansion & 4.35 & 0.81 & 4.20 & 0.92 & 4.12 & 0.76 & 4.28 & 0.78 & 0.428 \\
\hline A takeover decision & 4.12 & 1.09 & 4.06 & 0.90 & 4.23 & 0.90 & 4.29 & 0.71 & 0.771 \\
\hline Any new contracts won by the company & 4.35 & 0.60 & 4.24 & 0.91 & 4.28 & 1.01 & 4.43 & 0.70 & 0.882 \\
\hline The launch of a new project & 4.26 & 0.86 & 4.28 & 0.76 & 4.02 & 0.98 & 4.28 & 0.86 & 0.692 \\
\hline
\end{tabular}

Note. This table reports the Likert-Scale for questions about the perceptions of non-financial information from the prospect of research participants. A five-point Likert-Scale was used ranging from $1=$ 'Strongly disagree' to $5=$ 'Strongly agree. The participants include Fund Mangers (FM); (ii) Individual Investors (IV); (iii) Analysts (AN); and (iv) Stockbrokers (SB). This information is presented: (i) for all participants and individual groups. Finally, the $p$ - value for a test of equality of means across 4 different groups is provided (FM, IV, AN, SB).

\subsection{Kuwait Stock Market Participants' Perceptions of "Corporate Governance Information"}

Table 9 provides summary statistics for Kuwait stock market participants' perceptions of corporate governance information useful to investment decisions. A Kruskal-Wallis test showed that no significant differences between participants' perceptions were found, suggesting the importance of corporate governance information among research participants.

Table 9. Kuwait stock market participants' perceptions of corporate governance information useful to the investment decision

\begin{tabular}{llllllllll}
\hline \multirow{2}{*}{ Statements } & \multicolumn{3}{c}{ FM } & \multicolumn{2}{c}{ IV } & \multicolumn{3}{c}{ AN } & \multicolumn{3}{c}{ SB-value } \\
\cline { 2 - 10 } & Mean & SD & Mean & SD & Mean & SD & Mean & SD \\
\hline Academic qualification of board of directors & 3.44 & 1.31 & 3.83 & 1.03 & 3.79 & 1.15 & 3.83 & 1.16 & 0.492 \\
Position held by executive directors & 3.71 & 1.29 & 4.06 & 0.92 & 3.86 & 1.04 & 4.14 & 0.80 & 0.637 \\
Background of senior management & 4.21 & 0.98 & 3.93 & 1.01 & 3.88 & 1.17 & 4.06 & 0.98 & 0.621 \\
Directors' remuneration & 3.53 & 1.33 & 3.40 & 1.03 & 3.49 & 1.16 & 3.92 & 1.03 & 0.161 \\
Board's directorship of other companies & 3.53 & 1.31 & 3.70 & 0.96 & 3.60 & 1.09 & 3.94 & 0.98 & 0.594 \\
Age of directors & 3.44 & 1.35 & 3.30 & 1.11 & 3.36 & 1.03 & 3.83 & 1.08 & 0.157 \\
Corporate strategies & 4.24 & 1.09 & 4.35 & 0.75 & 4.35 & 1.09 & 4.36 & 0.87 & 0.861 \\
A change in chairman or board member/ large shareholder & 4.09 & 0.97 & 4.30 & 0.86 & 4.30 & 0.97 & 4.22 & 0.96 & 0.519 \\
\hline
\end{tabular}

Note. This table reports the Likert-Scale for questions about the perceptions of corporate governance information from the prospect of research participants. A five-point Likert-Scale was used ranging from $1=$ 'Strongly disagree' to 5 = 'Strongly agree. The participants include Fund Mangers (FM); (ii) Individual Investors (IV); (iii) Analysts (AN); and (iv) Stockbrokers (SB). This information is presented: (i) for all participants and individual groups. Finally, the $p$ - value for a test of equality of means across 4 different groups is provided (FM, IV, AN, SB). 


\subsection{Kuwait Stock Market Participants' Perceptions of "Corporate Social Information"}

Table 10 provides summary statistics for Kuwait stock market participants' perceptions of corporate social information useful to investment decisions. Again a Kruskal-Wallis test indicated that no significant differences between participants' perceptions were found, except for two statements: "participation in government social campaigns" and "community programs health and education)," where their (p-values were 0.047 and 0.000 ), respectively, indicating significant differences between some group of participants, although all have positive perceptions toward those two statements.

Table 10. Kuwait stock market participants' perceptions of corporate social information useful to the investment decision

\begin{tabular}{|c|c|c|c|c|c|c|c|c|c|}
\hline \multirow{2}{*}{ Statements } & \multicolumn{2}{|l|}{ FM } & \multicolumn{2}{|l|}{ IV } & \multicolumn{2}{|l|}{$\mathrm{AN}$} & \multicolumn{2}{|l|}{ SB } & \multirow[t]{2}{*}{ P-value } \\
\hline & Mean & SD & Mean & SD & Mean & SD & Mean & SD & \\
\hline $\begin{array}{l}\text { Participation in government social } \\
\text { campaigns }\end{array}$ & 3.32 & 1.39 & 3.35 & 1.05 & 3.33 & 1.27 & 3.86 & 0.82 & $* 0.047$ \\
\hline $\begin{array}{l}\text { Community programs (health \& } \\
\text { education) }\end{array}$ & 3.15 & 1.28 & 3.44 & 0.97 & 3.30 & 1.12 & 4.14 & 0.98 & $* 0.000$ \\
\hline Recruitment policy & 3.71 & 0.97 & 3.52 & 1.02 & 3.44 & 1.20 & 3.89 & 0.88 & 0.259 \\
\hline Number of employees & 3.76 & 1.08 & 3.50 & 0.99 & 3.79 & 1.01 & 3.78 & 0.89 & 0.490 \\
\hline $\begin{array}{l}\text { Percentage of foreign and national } \\
\text { labour force }\end{array}$ & 3.65 & 1.32 & 3.28 & 1.07 & 3.58 & 1.01 & 3.86 & 1.00 & 0.102 \\
\hline Improvement in product quality & 4.09 & 0.97 & 4.24 & 0.78 & 4.47 & 0.55 & 4.24 & 0.83 & 0.546 \\
\hline Improvement in customer services & 3.91 & 1.14 & 4.20 & 0.90 & 4.40 & 0.58 & 4.11 & 0.91 & 0.463 \\
\hline $\begin{array}{l}\text { Information on donations to } \\
\text { charitable organizations }\end{array}$ & 3.38 & 1.44 & 3.39 & 1.09 & 3.33 & 1.29 & 4.03 & 0.93 & 0.061 \\
\hline $\begin{array}{l}\text { Distribution of marketing network } \\
\text { of products }\end{array}$ & 4.15 & 1.05 & 3.98 & 0.94 & 3.81 & 1.12 & 4.19 & 0.88 & 0.084 \\
\hline
\end{tabular}

Note. This table reports the Likert-Scale for questions about the perceptions of corporate social information from the prospect of research participants. A five-point Likert-Scale was used ranging from $1=$ 'Strongly disagree' to 5 = 'Strongly agree. The participants include Fund Mangers (FM); (ii) Individual Investors (IV); (iii) Analysts (AN); and (iv) Stockbrokers (SB). This information is presented: (i) for all participants and individual groups. Finally, the $p$ - value for a test of equality of means across 4 different groups is provided (FM, IV, AN, SB).

\subsection{Kuwait Stock Market Participants' Perceptions of "Type of Valuation Methods Information"}

Table 11 provides summary statistics for Kuwait stock market participants' perceptions of type of valuation methods information useful to investment decisions. A Kruskal-Wallis test suggested that no significant differences between participants' perceptions were found, which suggests the importance of the valuation methods - namely, fundamental, risk, and technical analysis.

Table 11. Kuwait stock market participants' perceptions of type of valuation methods information useful to the investment decision

\begin{tabular}{|c|c|c|c|c|c|c|c|c|c|}
\hline \multirow{2}{*}{ Statements } & \multicolumn{2}{|c|}{ FM } & \multicolumn{2}{|c|}{ IV } & \multicolumn{2}{|c|}{ AN } & \multicolumn{2}{|c|}{ SB } & \multirow[t]{2}{*}{ P-value } \\
\hline & Mean & SD & Mean & SD & Mean & SD & Mean & SD & \\
\hline Technical Analysis & 4.38 & 0.74 & 4.15 & 0.88 & 4.23 & 0.99 & 4.19 & 0.78 & 0.544 \\
\hline Fundamental Analysis & 4.65 & 0.60 & 4.50 & 0.64 & 4.70 & 0.51 & 4.43 & 0.60 & 0.116 \\
\hline Risk Analysis & 4.41 & 0.70 & 4.38 & 0.66 & 4.47 & 0.67 & 4.32 & 0.71 & 0.799 \\
\hline
\end{tabular}

Note. This table reports the Likert-Scale for questions about the perceptions of type of valuation methods information from the prospect of research participants. A five-point Likert-Scale was used ranging from 1 = 'Strongly disagree' to 5 = 'Strongly agree. The participants include Fund Mangers (FM); (ii) Individual Investors (IV); (iii) Analysts (AN); and (iv) Stockbrokers (SB). This information is presented: (i) for all participants and individual groups. Finally, the $p$ - value for a test of equality of means across 4 different groups is provided (FM, IV, AN, SB).

\section{Conclusions}

The purpose of this paper is to report the results of an investigation into Kuwaiti multi-investors' perceptions of different types of information useful to investment decisions. Out of 410 questionnaires, 168 were useable and 
collected, constituting a response rate of $41 \%$. The questionnaire targeted key players in the Kuwaiti stock market - namely, analysts, fund managers, individual investors, and stockbrokers who are involved with investment decisions.

The study found that the most important source of information to most of the Kuwaiti users of "general corporate information" was information about major types of products (services). Also, the most important item under "financial information" was operating profit. In addition, the most important item under "nonfinancial information" was new contracts won by the company. Furthermore, the most important item under "corporate governance information" was corporate strategies. Moreover, the most important item under "corporate social information" was improvement in customer services. Finally, the most important item under "type of valuation methods" was fundamental analysis. On the contrary, friends' advice, ages of directors, tips and rumours, and information on donations to charitable organizations were seen as the least-used sources of information for investment decision-making.

The study found that the participants differed significantly in their perceptions of the importance of information about major types of products (services), realized and unrealized earnings, newspapers, auditors reports, participation in government social campaigns, and community programs health and education for investment decisions. Except for these, no significant differences between participants' perceptions were found, suggesting that corporations restructure their information systems to meet the demands of different users.

The results of this study reveal that the majority of participants rely on other sources of information beside financial information such as corporate governance, social, and nonfinancial information, suggesting that investors tend to use every piece of information available for investment decision-making.

It is hoped that this study will provide valuable insights and guidance to Kuwaiti regulators and preparers in improving corporate sources of information and, in turn, preparers could shape their information sources to the needs of its users. This is necessary in order for the corporation to keep current and attract more investments. In addition, regulators should consider encouraging Kuwaiti's listed companies to structure their information sources to more closely meet the demands of users.

Future research might examine whether participants grouped according to different characteristics (years of experience, education qualification, average amount of money invested, and type of industry) share the same investment decision-making process. Such future research could improve investment culture and explain the behavior of multi-user investors per their investment decisions. Another possible research path could be to conduct interviews or use a larger sample and additional groups of users, such as accountants, regulators, and institutional investors.

This study has been a cross-sectional examination. How the current pattern of corporate information sources will change over time is debatable, but clearly a longitudinal study will be needed in due course to obtain a fuller understanding and greater insight.

\section{References}

Abdelkarim, N., Shahin, Y., \& Arqawi, B. (2009). Investor Perception of Information Disclosed in Financial Reports of Palestine Securities Exchange Listed Companies. Accounting \& Taxation, 1(1), 45-61.

Abu-Nassar, M., \& Rutherford, B. A. (1996). External users of financial reports in less developed countries: The case of Jordan. British Accounting Review, 28(1), 73-87. http://dx.doi.org/10.1006/bare.1996.0004

Al-Ajmi, J. (2009). Investors' use of corporate reports in Bahrain. Managerial Auditing Journal, 24(3), 266-228. http://dx.doi.org/10.1108/02686900910941140

Al-Attar, J. M., \& Al-Khater, K. (2007). An empirical investigation of users' views on corporate annual reports in Qatar. International Journal of Commerce \& Management, 17(4), 312-325. http://dx.doi.org/10.1108/10569210710844381

Almujamed, H., Fifield, S., \& Power, D. (2012). Share Valuation Methods and Data Source-Based Accounting In An Emerging Stock Market: The Case of the Kuwaiti Stock Market. International Busniess \& Economics Research Journal, 11(7), 713-730.

Al-Razeen, A., \& Karbhari, Y. (2004). Users' Perceptions of Corporate Information in Saudi-Arabia: An Empirical Analysis. International Journal of Commerce and Management, 14(3/4), 41-57. http://dx.doi.org/10.1108/10569210480000183

Al Sawalga, F. (2012). Different Sources of Corporate Financial Information and Investment Decision Opportunity: Evidence from Amman Stock Exchange. International Journal of Business and Management, 
7(7), 110-120. http://dx.doi.org/10.5539/ijbm.v7n7p110

Al-Tamimi, H. (2006). Factors Influencing Individual Investor Behavior. The Business Review Cambridge, 5(2), $225-232$.

Alzarouni, A., Aljifri, K., Ng, C., \& Tahir, M. (2011). The Usefulness of Corporate Financial Reports: Evidence from the United Arab Emirates. Accounting \& Taxation, 3(2), 17-37.

Baker, H. K., \& Haslem, J. A. (1973). Information needs of individual investors. Journal of Accountancy, 136(5), 64-69.

Bartlett, S., \& Chandler, R. (1997). The corporate report and the private shareholder: Lee and Tweedie twenty years on. British Accounting Review, 29(3), 245-261.

Beaver. (2002). Perspectives on Recent Capital Market Research. Accounting Review, (77), 453-474.

Desoky, A. M. (2010). The perceived importance of electronic sources of financial information to individual investors in Egypt: An empirical investigation. Afro-Asian Journal of Finance and Accounting, 2(1), 70-87. http://dx.doi.org/10.1504/AAJFA.2010.035195

De Vellis, R. F. (2003). Scale development: Theory and applications (2n ed.). California, Sage: Thousand Oaks.

Mirshekary, S., \& Saudagaran, S. (2005). Perceptions and characteristics of financial statement users in developing countries: Evidence from Iran. Journal of International Accounting, Auditing and Taxation, 14, 33-54. http://dx.doi.org/10.1016/j.intaccaudtax.2005.01.001

Naser, K., Nuseibeh, R., \& Al-Hussaini, A. (2003). Users' perceptions of various aspects of Kuwaiti corporate reporting. Managerial Auditing Journal, 18(6/7), 538-548. http://dx.doi.org/10.1108/02686900310482731

Nunnally, J. C. (1978). Psychometric Theory (2nd ed.). New York: McGraw-Hill.

Saudagaran, S. M. (2004). International Accounting: A user perspective (2nd ed.). Ohio: South-Western College Publishing.

Scott, R. N., \& Smith, C. (1992). Corporate Annual Reports and the Information Needs of Individual Investors. Journal of Business and Finance Librarianship, 1(3), 3-18.

Zoysa, A., \& Rudkin, K. (2010). An Investigation of Perceptions of Company Annual Report Users in Sri Lanka. International Journal of Emerging Markets, 5(2), 183-202.

\section{Note}

Note 1. A total of 255 of the 410 distributed questionnaires were received for this research. However, 87 of the participants who filled out questionnaires were excluded from the analysis; this reduced the useable responses to 168. This decision was made because 37 of the respondents left most of the questions unanswered and the other 50 respondents did not invest in the KSE. These respondents were employees of the KSE and the Kuwait Clearing House $(\mathrm{KCH})$; some worked in the filing department for listed companies of the KSE, while others worked as accountants at the $\mathrm{KCH}$. Therefore, a decision was made to omit these responses.

\section{Copyrights}

Copyright for this article is retained by the author(s), with first publication rights granted to the journal.

This is an open-access article distributed under the terms and conditions of the Creative Commons Attribution license (http://creativecommons.org/licenses/by/3.0/). 